\title{
ERÄIDEN SUOMEN JULKISTEN NURMIKOIDEN PERUSTAMIS- JA HOITOTAVOISTA
}

\author{
Saija Ravantti \\ Hankkijan kasvinjalostuslaitos, koetila Anttila
}

Saapunut 11, 3. 1965

\begin{abstract}
Nurmikasveja on maassamme tutkittu etupäässä niitto- ja laidunnurmikasveina ja toistaiseksi vain vähän nurmikkokasveina. Kasvitautientutkimuslaitos ja Tuhoeläintutkimuslaitos ovat tutkimuksissaan huomioineet nurmikot $(5,6,7,8)$. Nurmikkokokeita on nykyisin Lepaan puutarhaopistolla, Yliopiston Puutarhatieteenlaitoksella, Puutarhakoelaitoksella ja Hankkijan koetilalla. Vain viimeksi mainittu on julkaissut kokeiden tuloksia (16).

Elintason noustessa on Suomessa kuten muuallakin maailmassa liiennyt varoja enemmän uusien, julkisten ja yksityisten viheralueiden perustamiseen ja vanhojen viheralueiden kunnostamiseen. Viheralueiden pohjan muodostaa nurmikko. Mielenkiinto nurmikkokysymyksiin on käytännössä suuri. Puutarha-alan lehdistössä ja oppikirjoissa esitetään nurmikoiden perustamis- ja hoito-ohjeita, jotka perustuvat kotimaisiin käytännön kokemuksiin ja usein uusimpien ulkomaisten kokeiden tulosten käytännön sovellutuksiin. Erikoisesti on oltu kiinnostuneita Weibullsholmin kasvinjalostuslaitoksen nurmikkokokeiden tuloksista (vrt. 3, 9, 12, 13, 15, 22, 24).

Käytettävissä ei ole tilastoa tai tutkimusta nykyisten nurmikoittemme perustamis- ja hoitotavoista. Tämän tutkimuksen tarkoituksena on selvittää, mitä perustamis- ja hoitomenetelmiä eräillä Suomen julkisilla nurmikoilla käytetään, ja minkälaisia käsityksiä on nurmikkojen erikoiskysymyksistä.
\end{abstract}

\section{Tutkimusaineisto}

Tutkimus perustuu syystalvella 1963 suoritettuun 306 kirjeen kyselyyn, jonka kohteena oli julkisten nurmikoiden hoitajia käsittäen kaikki Suomen silloiset 
kaupungit ja kauppalat, $23 \%$ maalaiskunnista, $92 \%$ maataloudellisista oppilaitoksista sekä Vierumäen urheiluopiston urheilukentän hoitajakurssien osaanottajat vuosina $1961-62$. Tiedustelun vastausprosentti oli $38 \%$. Taulukosta 1 ilmenee tiedustelun kohteiden vastausprosentit ja keskimääräiset nurmikkojen pinta-alat. Kaikkiaan tutkimus käsitti 1293.5 ha puisto- ja pihanurmikoita sekä 199.5 ha urheilukenttiä. Paitsi että eri vastaajaryhmien hoidettavana oli erisuuruisia nurmikkoaloja oli myös saman ryhmän eri jäsenien nurmikkoaloissa melkoista eroa. Esim. Helsingin kaupungilla on n. 400 ha puisto- ja pihanurmikoita, kun taas Kaskisten kaupungilla vain 1 ha.

Taulukko 1. Lähetetyt kirjeet ja saadut vastaukset

Table 1. Questionnaires sent and replies received

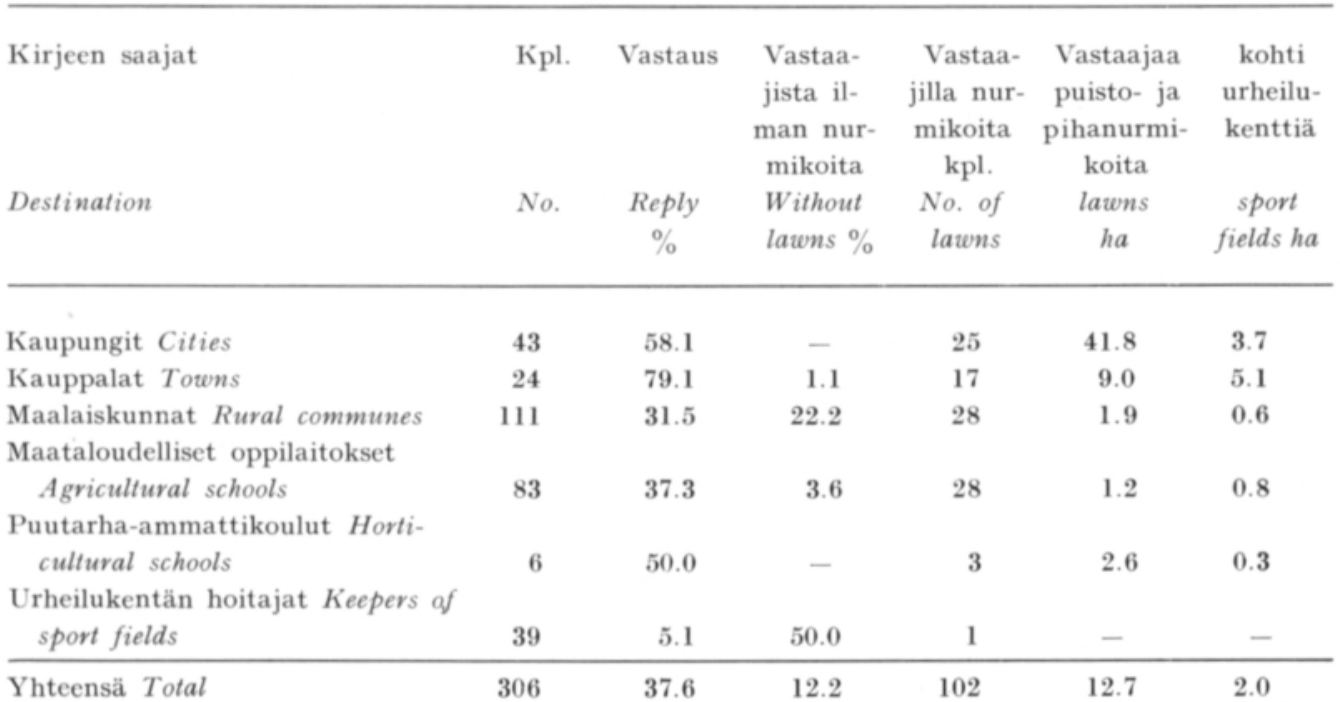

Tiedustelun vastaukset on käsitelty viiteen ryhmään jaettuna: kaupungit, kauppalat, maalaiskunnat, maataloudelliset oppilaitokset ja puutarha-ammattikoulut. Viimeksi mainittu ryhmä kuuluu oikeastaan ryhmään maataloudelliset oppilaitokset, mutta se on haluttu pienuudestaan huolimatta ottaa omaksi ryhmäkseen, koska nurmikon perustaminen ja hoito on ollut puutarha-ammattikoulujen opetusohjelmassa enemmän esillä kuin muiden maataloudellisten koulujen. Urheilukentän hoitajat on jätetty vähäisen vastausprosenttinsa vuoksi pois tarkastelusta.

Tiedustelu jakautui kolmeen osaan: nurmikkoseokset (13 kysymystä), nurmikon perustaminen (12 kysymystä) ja nurmikon hoito (23 kysymystä). Samaa jakoa noudatetaan tiedustelun vastausten tarkastelussa. Kaikkiin kysymyksiin vastasi 20 vastaajaa, osaan kysymyksistä 81 vastaajaa. Monissa tapauksissa nykyiset nurmikkojen hoitajat eivät ole niitä perustaneet ja tällöin tiedot perustamistavoista puuttuvat. 


\section{Tiedustelun tulokset}

\section{Nurmikkosiemenseokset}

Käytetyt seokset. Tiedusteluun vastanneista $67 \%$ ilmoitti käyttävänsä valmiita ostoseoksia, $23 \%$ sekä osto- että omia seoksia ja vain $10 \%$ aina omia sekoituksia. Eniten käyttivät ostoseoksia kaupungit ja vähiten maalaiskunnat. Ostoseoksien koostumus oli vain harvojen vastaajien tiedossa. Saaduista vähistä kuvauksista ilmeni, että paitsi varsinaisilla nurmikkosiemenseoksilla saatetaan nurmikoita perustaa myös laidunnurmiseoksilla. Näin oli asiantila 2 kauppalassa ja 4 maataloudellisessa oppilaitoksessa.

Yleensä oltiin sitä mieltä, että eri olosuhteissa tarvitaan erilaisia nurmikkoseoksia, vain maalaiskunnista lähes puolet piti yhtä seostyyppiä riittävänä.

Omien seoksien käyttäjät antoivat kuvauksen 68 seoksesta. Yhdeltä vastaajalta saatiin $1-7$ seoskuvausta. Yleisimpiä olivat $1-3$ kuvauksen antajat kaikissa vastausryhmissä. Kaupungit olivat ainoat $4-7$ erilaisen oman seoksen käyttäjät.

Nurmikasvilajien luku vaihteli omissa seoksissa $2-8$. Yleisimpiä olivat $3-6$ kasvilajia sisältävät seokset. Suurin oli lajiluku kaupunkien ja kauppaloiden seoksissa. Seoksissa esiintyivät seuraavat karkeat heinälajit: italialainen raiheinä (Lolium Multiflorum), englantilainen raiheinä (Lolium Perenne), timotei (Phleum pratense), nurminata (Festuca pratensis), koiranheinä (Dactylis glomerata) ja seuraavat hienot heinälajit: punanata (Festuca rubra), lampaannata (Festuca ovina), niittynurmikka (Poa pratensis), yleinen nurmikka (Poa trivialis), lehtonurmikka (Poa nemoralis), nurmirölli (Agrostis tenuis), rönsyrölli (Agrostis stolonifera), kampasukapää (Cynosarus cristatus) sekä seuraavat palkokasvit: valkoapila (Trifolium repens) ja puna-apila (Trifolium ptatense). Mainitut nurmikkokasvit ovat koiranheinää ja puna-apilaa lukuunottamatta käytössä nurmikkokasveina myös muualla Pohjoismaissa $(11,20,21,23,25)$. Koiranheinä ja puna-apila ovat yksinomaan niitto- ja laidunnurmikasveja. Puna-apilaa oli muutamien maalaiskuntien ja maataloudellisten oppilaitosten seoksissa, koiranheinää taas muutamien kaupunkien, kauppaloiden ja maataloudellisten oppilaitosten seoksissa.

Mainituista 68 omasta seoksesta oli vain $13 \%$ ilman karkeita heiniä. Suomessa on yleensä käytetty karkeaheinävaltaisia nurmikkoseoksia. Puutarhalehdistössämme on kuitenkin 1950-luvun puolivälistä lähtien suositeltu siirtymistä nurmikkoseoksiin, joissa karkeiden heinien osuus olisi alle 25 painoprosenttia. Suositukset perustuvat Weibullsholmin kasvinjalostuslaitoksen kokeiden tuloksiin. Tämän uuden suuntauksen rinnalla on kuitenkin edelleen karkeaheinävaltaisten seosten suosittelijoita (vrt. 3, 10, 14, 17, 18, 22).

Tarkastelun kohteena olevista omista seoksista oli yli 25 painoprosenttia karkeita heiniä sisältäviä maalaiskuntien seoksista $100 \%$, kauppaloiden $78 \%$, kaupunkien $76 \%$, maataloudellisten oppilaitosten $67 \%$ ja puutarha-ammattikoulujen $67 \%$. Enemmistön muodostivat seokset, joissa karkeita heiniä oli $30-50$ painoprosenttia. Suosituimmat karkeat heinät olivat englantilainen raiheinä ja nurminata. Karkeita heiniä sisältävistä 79 seoksesta oli $28 \%$ sellaisia, joissa oli vain yksi karkea heinälaji, muissa niitä esiintyi $2-6$ kappaletta. Mitään oleellista eroa ei ollut eri vastausryhmien suosimien karkeiden heinälajien välillä. 
Neljä yleisintä omien seoksien hienoa heinälajia olivat punanata (84 \% seoksia), niittynurmikka $(72 \%)$, nurmirölli $(38 \%)$ ja rönsyrölli $(21 \%)$. Muita hienoja heinälajeja oli käytetty vain kuivien ja kosteiden paikkojen erikoisseoksiin, joten niiden osuus oli pieni $(7-10 \%$ ). Kauppalat ja puutarha-ammattikoulut käyttivät seoksissaan enemmän niittynurmikkaa kuin punanataa. Röllit olivat selvästi runsaammin edustettuina kaupunkien, kauppaloiden ja puutarha-ammattikoulujen seoksissa kuin muiden ryhmien.

Valkoapila esiintyi $22 \%$ omista seoksista. Suosituin se oli maataloudellisten oppilaitosten seoksissa $(42 \%)$, kun taas puutarha-ammattikoulujen seoksista se täysin puuttui.

Kuvatuista 68 omasta seoksesta oli kaksi selvää laidunseosta. Yleensä oli seokset suunniteltu asiallisesti, vaikkakin karkeiden heinien ja valkoapilan osuus saisi olla pienempi. Uusimmat nurmikkojen siemenseoksien suunnitteluvirtaukset olivat selvimmin näkyvissä puutarha-ammattikoulujen, kaupunkien ja kauppaloiden seoksissa.

Nurmikkokasvien tuntemuksesta. Nurmikon kasvustokoostumuksen seuraaminen vaatii erikoisharrastusta ja aikaa. Kaupungeista $52 \%$, puutarha-ammattikouluista $33 \%$, maataloudellisista oppilaitoksista $33 \%$, maalaiskunnista $20 \%$ ja kauppaloista $18 \%$ ilmoitti seuraavansa jossain määrin nurmikkojen kasvuston kehitystä. Yleisin kasvi nurmikoissa oli niittynurmikka, seuraavina punanata, nurminata ja valkoapila. Maalaiskuntien yleisin nurmikkokasvi oli valkoapila, kaikkien muiden ryhmien niittynurmikka.

Kysymykseen, vaihteleeko seoksen pääkasvilaji kasvupaikan mukaan, vastasi $29 \%$ tiedusteluun vastaajista myöntävästi, kun taas $27 \%$ mielestä seoksen pääkasvilaji vaihtelee nurmen iästä riippuen. Tarkempi vaihtelun kuvaus oli yleisiä käsityksiä vastaava. Vain valkoapilan säilymisestä nurmikossa oli ristiriitaisia käsityksiä. Toiset väittivät sen nopeasti katoavan nurmikoista, kun taas toiset väittivät sen nurmikon vanhetessa lisääntyvän.

Vastaajia oli pyydetty ryhmittämään 18 lueteltua nurmikkokasvia paremmuusjärjestykseen. Tehtävän suoritti $56 \%$ kaikista vastaajista kokonaan tai osittain. Arvostelua vaikeutti se, etteivät kaikki tunteneet kyseisiä kasveja. Jotkut vastaajat pitivät tehtävää käsittämättömänä, koska heistä heinälajin arvo on erilainen eri olosuhteissa. Nurmikkokasvien paremmuusjärjestys muodostui seuraavaksi: niittynurmikka, punanata, nurminata, englantilainen raiheinä, nurmirölli, timotei, rönsyrölli, yleinen nurmikka, italialainen raiheinä, lampaannata, lehtonurmikka, koiranheinä, kylänurmikka, villitimotei, kampasukapää, jäykkänata, ruokomainen nata ja ruokohelpi. Eri vastaajaryhmien välillä ei ollut suuria eroja. Arvostetuin nurmikkoheinälaji oli kaikilla muilla vastaajaryhmillä niittynurmikka tai punanata mutta maalaiskunnilla nurminata. Saatu heinien arvostusjärjestys on samansuuntainen kuin se arvostus, joka heijastui suosituimmista heinistä omissa seoksissa.

Valkoapilan arvostus on myös suuri, koska hyvänä tai tyydyttävänä nurmikkokasvina sitä piti kauppaloista $82 \%$, maataloudellisista oppilaitoksista $78 \%$, maalaiskunnista $67 \%$, puutarha-ammattikouluista $67 \%$ ja kaupungeista $56 \%$. Huonona nurmikkokasvina sitä piti vain $4 \%$ kaikista tiedusteluun vastaajista. Eräiden 
ulkomaisten nurmikkoasiantuntijoiden käsitys, että valkoapila on rikkaruoho nurmikoissa, ei siis saanut juuri kannatusta $(2,4,25)$.

Nurmikkosiemenseoksien suunnittelussa huomioonotettavaa. Käsityksensä nurmikkoseoksien suunnittelussa huomioonotettavista asioista ilmaisi $75 \%$ kaikista tiedustelun vastaajista. Eniten korostettiin seuraavia asioita: talvenkestävyys, kasvuolosuhteet sekä tallauksen- ja kuivuuden kestävyys. Huomionarvoisina mainittiin lisäksi hidaskasvuisten heinälajien valinta, kaunis ulkonäkö, tiheä kasvutapa, nurmikon käyttötapa, raiheinän sopiva määrä, niiton kestävyys, seoksen hinnan halpuus, mätästämättömät lajit ja seoksen lajirunsaus. Oleellista eroa ei ollut eri vastaajaryhmien huomioonotettavien asioiden välillä. Ainoastaan Lepaan puutarhaopisto mainitsi nurmikkokasvien $1000 \mathrm{sp}$ ja orastumiskyvyn huomioonotettavana nurmikkoseoksien suunnittelussa. Näitä seikkoja korostetaan erityisesti ammattikirjallisuudessa $(20,21,22,25)$.

\section{Nurmikon perustaminen}

Maan muokkaus ja lannoitus. Sopivampana nurmikon ruokamultana pitivät kaikki vastaajaryhmät viljelyksellisesti parhaimpia maalajiamme, multavaa hietaja hiuesavea sekä hienoa hietaa. Näitä maalajeja on kuitenkin vain harvoin saatavissa ruokamullaksi ja siksi käytettiin yleisesti (81\% vastaajista) maanparannusaineita, joista suosituin oli suomuta (53\% vastaajista). Suomudan suureen suosioon vaikuttavat maataloudelliset perinteet, sillä aiemmin käytettiin maassamme suomutaa runsaasti kivennäismaapeltojen maanparannusaineena. Muina maanparannusaineina mainittiin kalkki, komposti, hiekka, savi, turve ja sora.

Nurmikon peruslannoitustarve tunnustetaan, koska $100 \%$ puutarha-ammattikouluista, $92 \%$ kaupungeista, $88 \%$ kauppaloista, $79 \%$ maalaiskunnista, $75 \%$ maataloudellisista oppilaitoksista ilmoitti käyttävänsä peruslannoitusta. Sen vastustajien käsityksen mukaan lannoitus vain lisää nurmikon kasvua, jolloin ennestäänkin kallis niittokustannus nousee. Kuitenkin on selvästi todistettu, että vain lannoitettu nurmikko muodostuu tiheäksi, kauniin väriseksi, rikkaruohottomaksi, poudan-, talven- ja tallauksenkestäväksi $(2,4,23)$.

Peruslannoituksen käyttäjistä $70 \%$ lannoitti tehokkaasti käyttäen kolmea pääravinnetta $(\mathrm{N}, \mathrm{P}, \mathrm{K}), 23 \%$ käytti kahta pääravinnetta $(\mathrm{P}, \mathrm{K})$ ja $5 \%$ pelkkää fosforilannoitusta ja $2 \%$ typpilannoitusta. Kaupungit käyttivät vähiten monipuolista lannoitusta suosien fosfori-kalilannoitusta. Toisaalta ne turvautuivat vähiten yksipuoliseen lannoitukseen, jota taas maataloudelliset oppilaitokset käyttivät eniten. Fosfori-kalilannoitus peruslannoituksena on hyvä, jos myöhemmin taimettumisen jälkeen huolehditaan typpilannoituksesta. Moniravinteiset Y-lannokset olivat yleisimmin käytettyjä ravinteita ja vain maataloudelliset oppilaitokset suosivat l-ravinteisia lannoitteita. Karjanlantaa käytettiin maalaiskunnissa ja maataloudellisissa oppilaitoksissa myös peruslannoitukseen runsaammin kuin muualla. Kyselyn tulokset eivät salli mahdollisuutta tarkastella, onko annettu riittävästi kasvinravinteita ja oikein tasapainoitettuna.

Ennen nurmikon varsinaista perustamista pidetään suotavana pohjamaan tasausta $(2,20,25)$. Tämän tavan yleisyyttä ei tiedusteltu, mutta nurmikon muok- 
kaustavan kuvaukset antavat syytä olettaa, että pohjamaan tasaus on ollut kaupungeissa, kauppaloissa ja puutarha-ammattikouluissa yleistä, muttei maalaiskunnissa ja maataloudellisissa oppilaitoksissa.

Paikalliset olosuhteet, perustettavan nurmikon pinta-ala ja käytettävissä olevat työvälineet ratkaisevat, miten varsinainen kylvömuokkaus tapahtuu. On ymmärrettävää, että kyntö ja äestys kylvömuokkauksena oli yleistä maaseudulla (maalaiskunnat ja maataloudelliset oppilaitokset). Puutarha-ammattikouluissa, kaupungeissa ja kauppaloissa taas muokattiin jyrsimillä. Yleisenä pyrkimyksenä oli saattaa ruokamulta muokkaustoimenpitein hienojakoiseksi, mutta ilmavaksi, maan pinta tasatuksi lanalla tai haravalla sekä lopuksi ruokamulta tiivistetyksi miehen kantavaksi jyräyksin. Kuitenkin kaikissa vastaajaryhmissä oli muutamia tavallisen niittoja laidunnurmen muokkaustavan tai omalaatuisten, epäonnistuneiden muokkaustapojen käyttäjiä.

Kylvö. Käsinkylvöä käytti $94 \%$ kaikista vastaajista. Konekylvön käyttäjiä oli kaupungeista $8 \%$, maalaiskunnista $17 \%$ ja maataloudellisista oppilaitoksista $25 \%$. On selvää, että maaseudulla, jossa on totuttu työskentelemään koneilla niitto- ja laidunnurmien kylvössä, niitä käytetään myös nurmikoiden kylvössä. Yleisin kylvökone oli tavallinen heinänsiemenen kylvökone. Vain jokunen on käyttänyt vannaskylvökonetta.

Normaalina nurmikon kylvömääränä pidetään $1-3 \mathrm{~kg} / \mathrm{a}$. Vastaajista $69 \%$ ilmoitti käyttäneensä $2-4 \mathrm{~kg} / \mathrm{a}$ siementä, $13 \%$ käytti $1-2 \mathrm{~kg} / \mathrm{a}, 6 \% 4-5 \mathrm{~kg} / \mathrm{a}$, $1 \% 8-10 \mathrm{~kg} / \mathrm{a}$ ja $11 \% 0.2-0.8 \mathrm{~kg} / \mathrm{a}$ siementä. Pienempien siemenmäärien käyttäjät olivat maataloudelliset oppilaitokset ja maalaiskunnat. Nämä siemenmäärät ovat lähellä laidun- ja niittonurmien siemenmääriä.

Vastaajista $85 \%$ multasi siemenensä haravalla. Kaupungit, maalaiskunnat ja maataloudelliset oppilaitokset käyttivät jonkin verran myös erilaisia äkeitä. Yksi kaupunki ja yksi maalaiskunta ilmoitti peittävänsä kylvöksen ohuella multakerroksella.

Multauksen jälkeen päätti kylvötyöt jyräyksellä $85 \%$ vastaajista. Puutarhaammattikoulut ja kaupungit käyttivät sitä eniten, maataloudelliset oppilaitokset vähiten,

Nurmikon perustamisessa huomioonotettavaa. Mielipiteensä nurmikon perustamisessa huomioonotettavista asioista ilmaisi $80 \%$ tiedusteluun vastanneista. Eniten korostettiin riittävän ja tasaisen ruokamultakerroksen ja kylvöajan kosteusolosuhteiden merkitystä. Näiden lisäksi mainittiin seuraavat asiat: riittävä lannoitus, kunnollinen kylvömuokkaus, sopiva siemenseos, maan laatu, pohjamaan hikevyys, kylvön tasaisuus, pohjamaan hyvä tasaus, jyrääminen, siemenen multaus, rikkaruohoton maa, riittävä siemenmäärä ja perustamisen jälkeinen talvi.

\section{Nurmikon hoito}

Vuotuislannoitus. Säännöllisistä vuotuislannoitusta käytti tiedusteluun vastanneista $77 \%$. Yleisempää se oli puutarha-ammattikouluissa ja kaupungeissa kuin kauppaloissa ja maalaiskunnissa. Vähiten vuotuislannoitusta käyttivät maatalou- 
delliset oppilaitokset (71\%). Täyslannoitusta NKP:llä käytti $75 \%$, yksipuolista $\mathrm{N}$-lannoitusta $23 \%$ - P-lannoitusta $1 \%$ - ja K-lannoitusta $1 \%$ vastaajista. Maataloudelliset oppilaitokset käyttivät enemmän kuin muut ryhmät yksipuolista N-lannoitusta $(40 \%$ vastaajista). Täyslannoituksessa olivat moniravinteiset Ylannokset yksinään (53\% vastaajista) tai lisättynä jollain l-ravinteisella lannoitteella useimmiten typellä $(18 \%)$ yleisimpiä kuin l-ravinteiset lannoitteet $(29 \%)$. Maataloudelliset oppilaitokset käyttivät eniten l-ravinteisia lannoitteita $(50 \%$ vastaajista). Nopeasti liukeneva kalkkisalpietari oli yleisin typpilannoite. Vain maataloudelliset oppilaitokset käyttivät hitaammin liukenevaa oulunsalpietaria (50\% vastaajista).

Koko vuotuislannoitus annettiin yleensä keväällä. Vain 2 kauppalaa ja 2 maataloudellista oppilaitosta levitti typen 2-3 erässä sekä Lepaan puutarhaopisto 4 erässä kasvukauden aikana. Vain $35 \%$ lannoitusasioiden vastaajista ilmoitti käyttämänsä lannoitemäärät. Ne eivät vastanneet nurmikoille suositeltua pääravinteiden suhdetta $3 \mathrm{~N}, 1 \mathrm{P}$ ja $2 \mathrm{~K}$. Määrät olivat muutamia poikkeuksia lukuunottamatta pienempiä kuin kirjallisuuden suosittelemat (vrt. 2, 20, 24, 25).

Kevätharavointi, nurmikon paikkaus ja jyräys. Keväisistä hoitotoimenpiteistä yleisin oli haravointi. Sen suoritti $91 \%$ vastaajista, kauppalat ja maataloudelliset oppilaitokset harvemmin kuin muut ryhmät. Apusiemennykseen turvautui tarvittaessa $75 \%$ vastaajista. Yleisintä se oli kaupungeissa ja kauppaloissa. Vain $23 \%$ vastaajista jyräsi keväisin nurmikkonsa. Ilmeisesti on tunnettua, että nurmikkomme eivät kaipaa enää tiivistystä vaan enemmän tuulettamista. Jyräyksellä voidaan painaa vain rousteen nostamat taimet maahan, muttei tasata nurmikon pintaa. Nurmikon tasaamiseen on kattaminen paras keino $(2,19,20,25)$.

Niitto. Moottorikäyttöistä ruohonleikkuria käytti $72 \%$, työnnettäviä ruohonleikkureita tai heinänniittokoneita $16 \%$ ja viikatetta (etupäässä luiskissa) $12 \%$ vastaajista. Viimeeksi mainitut niittovälineet olivat yleisimpiä maalaiskuntien ja maataloudellisten oppilaitosten pienillä nurmikoilla kuin muualla.

Puolet kaikista vastaajista suorittaa nurmikon niiton keskimäärin kerran tai useammin viikossa, $31 \%$ vastaajista 2 viikon, $7 \% 3$ viikon, $11 \% 1$ kuukauden ja $1 \% 2$ kuukauden väliajoin. Maalaiskunnat ja maataloudelliset oppilaitokset niittävät nurmikkonsa harvemmin kuin muut ryhmät. Vastaajista $41 \%$ pyrki niittämään nurmikon $2-4 \mathrm{~cm}$ sänkeen. Muut niittivät etupäässä korkeampaan sänkeen. Puutarha-ammattikoulut ja kaupungit korostivat enemmän kuin muut ryhmät, että sängen korkeutta määrättäessä on huomioonotettava sääolot.

Niitto oli vastaajien enemistön mielestä suoritettava riittävän usein ja säännöllisesti, jottei tarvitsisi haravoida niittojätettä pois, kuitenkin mukautuen nurmikon kasvurytmiin. Eräät kaupungit ja kauppalat pitivät niittokustannusten alentamista tärkeänä, koska se nykyisin on suhteettoman korkea.

Kastelu. Nurmikon keinokastelun mahdollisuus riippuu seudun vesivaroista, nurmikon pinta-alasta ja varojen saannista sadettajien hankkimiseen. Kastelumahdollisuus oli kaikilla puutarha-ammattikouluilla, kaupungeista $88 \%$ :lla, maalaiskunnista $86 \%$ :lla, kauppaloista $71 \%$ :lla ja maataloudellisista oppilaitoksista $68 \%: l l a$. Kaupungit, suurimpien viheralueiden hoitajat pystyivät hankkimaan tehokkaimmat ja kalliimmat sadettajat. Vastaajien enemistön mielestä antaa par- 
haimman tuloksen harvoin tapahtuva, perusteellinen ja hienojakoinen kastelu iltaisin suoritettuna. Vain jotkut maalaiskunnat ja maataloudelliset oppilaitokset kannattivat usein tapahtuvaa niukkaa kastelua.

Rikkaruohojen torjunta. Rikkaruohojen esiintymiseen nurmikoissa on kiinnitetty huomiota, koska tiedusteluun vastanneista $83 \%$ nimesi nurmikkojen pahimmat rikkaruohot. Pahin rikkaruoho oli kaikkien vastaajaryhmien mielestä voikukka (Taraxacum vulgare) toiseksi pahin piharatamo (Plantago major). Muut mainitut rikkaruohot olivat: juolavehnä (Elytrigia repens), leskenlehti (Tussilago farfara) sammaleet (Bryohpyta), syysmaitiainen (Leontodon autumnalis), rönsyleinikki (Ranunculus repens), valvatit (Sonchus sp.), sian kärsämö (Achillea millefolium), lutukka (Capsella sp.), pelto-ohdake (Cirsium arvense) ja jauhosavikka (Chenopodium album).

Rikkaruohoja torjui vastaajista $56 \%$. Yleisempää se oli puutarha-ammattikouluissa, kaupungeissa ja kauppaloissa kuin maataloudellisissa oppilaitoksissa ja maalaiskunnissa. Yleisin torjuntatapa oli kemiallinen torjunta, mutta pienillä aloilla turvauduttiin myös käsinperkuuseen. Kaupungit ja puutarha-ammattikoulut käyttivät etupäässä 2,4-D-valmisteita, muut MCPA-valmisteita.

Kasvitautien ja tuhoeläinten torjunta oli vähäistä. Kolme kaupunkia ilmoitti joskus käyttävänsä PCNB-valmisteita talvituhosienien torjunnassa. Eräs puutarha-ammattikoulu käytti endriinivalmisteita myyrien torjuntaan. Ilmeisesti tuholaisten vauriot tiedustelun piiriin kuuluvilla nurmikoilla olivat pienet. Kasvitautien ja tuhoeläinten aiheuttamat vauriot nurmikoilla ovatkin ilmeisesti viileässä ilmastossa vähäisemmät kuin lauhkeassa ja lämpimässä ilmastossa $(1,6,25)$.

Nurmikoiden uusimistarvetta on vaikea arvioida. Vastaajista $55 \%$ yritti kuitenkin määritellä, miten usein suunnilleen joudutaan nurmikkoja uusimaan. Noin $68 \%$ heistä uusi nurmikkonsa $1-10$ vuoden väliajoin, $27 \% 10-20$ vuoden väliajoin ja vain $5 \%$ yritti paikkaamalla välttää uusimisen. Ankarat talvehtimisolosuhteemme ilmeisesti aiheuttavat sen, ettei saada perustetuksi ns. englantilaistyyppisiä ikuisia nurmikoita.

Yleiskäsitys nurmikon hoidosta. Käsityksensä tärkeimmistä nurmikon hoitotoimenpiteistä ilmaisi $72 \%$ tiedustelun vastaajista. Kaikki vastaajaryhmät olivat yksimielisiä siitä, että tärkeintä nurmikon hoidossa on riittävä lannoitus, säännöllinen niitto ja kastelu tarvittaessa. Lisäksi mainittiin seuraavat hoitotoimenpiteet (tärkeysjärjestyksessä): rikkaruohojen ja sammaleen torjunta, kevätharavointi, apusiemennys, nurmikon niitto lyhyeksi ennen talven tuloa, kulkemisen estäminen talvella nurmikolla sekä maan tuulettaminen.

\section{Tulosten tarkastelua}

Kiertokyselyn tulokset osoittivat, että suurin osa julkisista nurmikoistamme on todellisia, hoidettuja nurmikoita. Kaupungit ja kauppalat sekä puutarha-ammattikoulut perustavat ja hoitavat nurmikkonsa voimaperäisimmin sovelluttaen käytäntöön mahdollisuuksiensa mukaan nurmikkoalan uusimpia menetelmiä. Myös maalaiskuntien ja maataloudellisten oppilaitosten nurmikoista osa on voimaperäisesti hoidettuja, mutta keskimäärin ne ovat heikompia kuin muiden hoitajaryhmien. 
Nurmikkoseoskysymyksissä ovat mielipiteet vanhoillisempa kuin nurmikon perustamista tai hoitoa koskevissa. Niitto- ja laidunnurmien karkeita heinälajeja ja valkoapilaa arvostetaan myös nurmikkokasveina. Nurmikon perustamisessa ja hoidossa noudatetaan etupäässä ammattikirjallisuuden suosittelemia menetelmiä. Perus- ja vuotuislannoituksen monipuolisuus on monien hyväksymä, mutta lannoitteiden käyttömäärät ovat pienet ja väärin tasapainoitetut. Tähän lienee eräänä syynä pyrkimys pieniin perustamis- ja hoitokustannuksiin. Voimakkaan lannoituksen seuraus on paitsi suurempi lannoitekustannus myös suurentunut niittokustannus. Taloudelliset syyt rajoittavatkin huomattavasti nurmikkojen perustamisenja hoidon voimaperäistymistä.

Kirjoittaja esittää parhaat kiitoksensa kaikille tiedusteluun vastanneille ja erityisesti lehtori LeIf Simbergille hänen antamistaan arvokkaista neuvoista.

\section{KIRJALLISUUS}

(1) Couch, H. B. 1961. Diseases of turfgrasses. 288 p. New York.

(2) Eisele, C. 1962. Rasen Gras und Grünflächen. 134 S. Berlin.

(3) Fontell, C. I. 1953. Om fröblandningar till gräsmattor. Trädgårdsnytt 3: 6-7., 7: 8 .

(4) Harper, J. C. \& Hein, M. A. \& Juska, F. V. 1962. Better lawns establishment, maintenance, renovation, lawn problems, grasses. Home and Garden Bull. No 51. U.S.A. Dep. Agric.: p. 32 .

(5) Jamalainen, E. A. 1958. Kasvien talvehtimisesta ja sen parantamismahdollisuuksista. Kasvinsuoj. seur. julk. 13: 1-39.

(6) - - 1963. Die Auswinterung bei Futtergräsen und ihre Verhütung in Finland. Schriftenreihe der Karl-Marx-Universität Leipzig zur Fragen der sozialistischen Landwirtschaft, Heft 8. Krankheiten und Schädlinge am Futtergräsen: 139-154.

(7) Kanervo, V. 1959. Survey of agricultural pest research in Finland during a period of 60 years (1898-1958). Valt. maatal. koetoim. julk. 178: 5-13.

(8) - - \& VAPpUlA, N. A. 1962. Ủber Schädlingsforschungen und Bekämpfungsversuche in Mittel- und Nordfinnland. Ann. Agr. Fenn. 1: 49-71.

(9) Kivivuori, E. 1956. Puutarhojemme nurmikot. Puutarha 59: 328-329.

(10) KujanpäÄ, M. 1963. Nurmikot. Meidän perheen puutarha: 41-47. Helsinki.

(11) Langvad, B. 1962. Orienterade gräsförsök i Norrland och Nord-Norge. Weibulls Gräs Tips: 89 -95.

(12) - - 1963. Nurmikenttien perustaminen. Weibulls Allehanda. Erikoisnumero Suomea varten: $17-21$.

(13) LempiÄInen, L. 1964. Koristenurmien talvehtimisesa. Puutarha 67: 8-10.

(14) Lokonen, P. 1958. Kotipihat viihtyisiksi. Puutarhal. opaskirj. 9: 92.

(15) Luostarinen, K. 1954. Pihanurmen puolesta. Kaunis koti 36: 6-7.

(16) Ravantti, S. 1965. Nurmikkokokeet. (Summary: Lawns trial.) Siemenjulkaisu 1965: $205-224$.

(17) Salonen, F. \& HaApanen, A. 1952. Nurmikot. Uusi puutarhakirja 2: 15-21. Porvoo.

(18) - - \& JaAtinen, K. 1961. Ruohonurmikot. Kodinpuutarha: 303-309. Porvoo.

(19) Savonlahti, O. 1960. Jyrä pelottava väline. Puutarha 63: 231.

(20) Simberg, L. 1960. Nurmikot. Kodin puutarhatieto: 89-105. Porvoo.

(21) Sonesson, N. 1962. Ruohonurmikot. Suuri puutarhakirja 2: 540-543. Helsinki.

(22) TUURI, J. 1961. Nurmikkoheinistä. Puutarhakalenteri 20: 207-210.

(23) Weibull, G. 1958. Experiments with turfgrasses 1948-55. Agric. Horti. Genet. 16: 209-220.

(24) - - 1961. Nurmikot vaativat hoitoa syksylläkin. Puutarha 64: $398-400$.

(25) - 1962. Den gröna mattan. $95 \mathrm{~s}$. Stockholm. 
S U M M A R Y :

METHODS OF ESTABLISHMENT AND MANAGEMENT OF PUBLIC LAWNS IN FINLAND

Saija Ravanti

Hankkija's Plant Breeding Station, Experimental Farm Anttila

The purpose of this study was to examine the methods of establishment and management of public parks, lawns ans sport fields in Finland and the ideas held by professional gardeners on this subject. The study is based on the replies in 3 C 6 questionnaires sent in 1963 to the gardeners responsible for managing public lawns (Table 1). The questionnaire as well as the present report are divided into three parts: seed mixtures, lawn establishment and lawn management. The replies are grouped into five categories: cities, market towns, rural, communes, agrieultural schools and horticultural schools.

Laun seed mixtures. The use of purchased seed mixtures is common among the persons questioned the only exception being the cities. In most cases the composition of the mixture was not given. The compositions of 68 mixtures prepared by the gardeners themselves were given, consisting usually of 3-6 different species. The following coarse-textured grasses occurred in the mixtures: Lolium perenne, Lolium multiflorum, Phleum Pratense, Festuca pratensis and Dactylis glomerata. The following fine-textured grasses were present: Festuca rubra, Festuca ovina, Poa pratensis, Poa trivialis, Poa nemoralis, Agrostis tenuis, Agrostis stolonifera and Cynosarus cristatus. In addition, the mixtures contained white and red clover. Of the 68 mixtures, only $13 \%$ were without coarse grasses. Of the mixtures containing coarse grasses, those with more than $25 \%$ by weight of coarse grass species comprised $100 \%$ of the mixtures in the rural communes, $78 \%$ in the towns, $76 \%$ in the cities, $67 \%$ in acricultural schools and $67 \%$ in horticultural schools. Red fescue and common meadow grass were highly placed among all lawn grasses. White clover received an unduly favourable judgement.

Lawn establishment. The best types of soil for lawns are considered to be humusrich sandy clay, loamy clay and fine finesand. Poorer soiltypes are also used and to these various soil amendments are added, of which the most common is decomposed peat. The usual tillage implement in urban areas is the rotary cultivator, while in rural districts the plough and harrow are most commonly used. Basic fertilizations are given in $92 \%$ of the cities, $88 \%$ of the towns. $79 \%$ of the rural communes, $75 \%$ of the agricultural schools and $100 \%$ of the horticultural schools. In $70 \%$ of the cases PKN-fertilization is used, in $23 \%$ PK-fertillization, in $5 \% \mathrm{P}$-fertilization and in $2 \% \mathrm{~N}$-fertilization. The survey results do not indicate whether sufficient and correctly balanced amounts of the nutrients were used. In $94 \%$ of the cases the lawns were sown by hand. Mechanical seeding is more common in the rural communes and agricultural schools than elsewhere. In the former places the seed rates are generally too low being those used on pasture or at most only twice the pasture rate. The usual seed rate is $2-4 \mathrm{~kg} / \mathrm{a} .85 \%$ of the persons questioned reported earthing the seed with a rake. Rolling after seeding is a general practice. The persons questioned consider the most important factors in lawn establishment to be an adequate and uniform layer of topsoil and sufficient moisture at the time of seeding.

Lawn management. The value of annual dressings of chemical fertilizers is generally well understood, since $77 \%$ of the questionnaires reported using such dressings. In $75 \%$ of the cases multi-nutrient fertilizers are used, while agricultural schools tend to employ only nitrogen. In general, nitrogen is applied as a single dressing in the spring; only in $7 \%$ of the cases were $2-4$ applications made during the course of the growing season. It appears that the annual dressings are often inadequate and are not properly balanced between the different nutrients if the recommendations by WEIBULL (32) are considred to be correct. Raking of lawns in the spring was reported in $91 \%$ of the questionnaires. Compacting of lawns by rolling in the spring was performed in only $28 \%$ of the cases. On the other hand, $75 \%$ reported reseeding on the bare spots. Mowing is chiefly performed by a motor-driven lawn mower. $50 \%$ of the gardeners reported mowing at least once a week; in rural communes and at the agricultural schools mowing is less frequent than in the other places. Facilities for watering the lawns are available in $100 \%$ of the horticultural schools, $88 \%$ of the cities, $86 \%$ of the rural communes, $71 \%$ of the towns, and $70 \%$ of the agricultural schools. The persons questioned consider the most important factors in watering to 
be thorough drenching and fineness of the spray. $56 \%$ of the questionnaires reportes a control of weeds on the lawns. The most common weeds according to this survey were Taraxacum vulgare and Plantago major. On the larger lawn areas chemical control is commonly employed. Control of plant diseases and pests on lawns is limited. Owing to the rigorous winters in Finland it is difficult to maintain permanent lawns and the lawns must be renewed from time to time. On the basis of the present results, $68 \%$ of the lawns are renewed at intervals of $1-10$ years. The persons questioned in this survey believe the three most important factors in proper lawn management to be ample dressings of chemical fertilizers, regular mowing and sufficient watering.

The cities, the horticultural schools and the towns establish and manage lawns on an average more intensively than the agricultural schools and the rural communes.

\section{MAATALOUSTIETEELLINEN AIKAKAUSKIRJA} TOIMITUSKUNTA

Erkki Kivinen, Jaakko Mukula, Antti Mäki, Alpo Reinikainen, Orvo Ring

\section{E. A. Jamalainen}

Päätoimittaja

Tikkurila. Puh. 831419 ja 831318

MAATALOUSTIETEELLIST $\AA$ AIKAKAUSKIRJAA

ilmestyy 4 vihkoa vuodessa

Käsikirjoitukset lähetetään päätoimittajalle (os. Tikkurila) tai jollekin toimifusvaliokunnan jäsenelle

SUOMEN MAATALOUSTIETEELLINEN SEURA

Puheenjohtaja:

Tohtori Martti Sipilä

Kaarela, Helsinki

Varapuheenjohtaja:

Tohtori August Jäntti

Mechelinink. 2 A, Helsinki
Sihteeri:

Tohtori Kalle Maijala

Tikkurila

Rahastonhoitaja:

Tohtori Leo Yllö

Tikkurila

Kirjastonhoitaja:

Maisteri Majlis Tulander, Hallituskatu 3, Helsinki 